\title{
Significant implications of permafrost thawing for climate change control
}

\author{
Mikel González-Eguino ${ }^{1,2} \cdot$ Marc B. Neumann ${ }^{1,3}$
}

Received: 2 November 2015 / Accepted: 28 March 2016/Published online: 11 April 2016

C The Author(s) 2016. This article is published with open access at Springerlink.com

\begin{abstract}
Large amounts of carbon are stored as permafrost within the Arctic and sub-Arctic regions. As permafrost thaws due to climate warming, carbon dioxide and methane are released. Recent studies indicate that the pool of carbon susceptible to future thaw is higher than was previously thought and that more carbon could be released by 2100 , even under low emission pathways. We use an integrated model of the climate and the economy to study how including these new estimates influence the control of climate change to levels that will likely keep the temperature increase below $2{ }^{\circ} \mathrm{C}$ (radiative forcing of $2.6 \mathrm{Wm}^{-2}$ ). According to our simulations, the fossil fuel and industrial $\mathrm{CO}_{2}$ emissions need to peak 5-10 years earlier and the carbon budget needs to be reduced by $6-17 \%$ to offset this additional source of warming. The required increase in carbon price implies a 6-21\% higher mitigation cost to society compared to a situation where emissions from permafrost are not considered. Including other positive climate feedbacks, currently not accounted for in integrated assessment models, could further increase these numbers.
\end{abstract}

\section{Introduction}

Permafrost (permanently frozen ground) is a major component of the cryosphere and occupies $24 \%$ of the Northern Hemisphere's land surface (Zhang et al. 2008). Observed warming in this area during the last 30 years was as high as $3{ }^{\circ} \mathrm{C}$ in parts of Northern Alaska and as high as $2{ }^{\circ} \mathrm{C}$ in parts of the Russian European North, between two to three times the global average (IPCC 2013). A reduction in permafrost thickness and surface area has been observed (Brown and Romanovsky 2008). As previously frozen soils thaw, substantial quantities of organic carbon become available for decomposition by soil microbes. Permafrost contains twice as much carbon as is currently stored in the atmosphere (Zimov et al. 2006) and the release of a

Mikel González-Eguino

mikel.gonzalez@bc3research.org

1 Basque Centre for Climate Change (BC3), Alameda de Urquijo, 4, 48008 Bilbao, Spain

2 University of the Basque Country (UPV/EHU), Bizkaia, Spain

3 IKERBASQUE, Basque Foundation for Science, Bilbao, Spain 
small fraction - in the form of carbon dioxide $\left(\mathrm{CO}_{2}\right)$ and methane $\left(\mathrm{CH}_{4}\right)$ - may lead to a positive feedback and increase the rate of future climate change (Burke et al. 2012).

The first studies estimated a permafrost carbon pool of almost 1700 gigatons (Gt) (see for an overview Zimov et al. 2006 or Schuur et al. 2008). New lines of evidence (Schuur et al. 2015), based on recent observations, show that substantial amounts of carbon are also accumulated in deeper areas and that these are susceptible to future thaw. Recent evidence also suggests that the most likely process is a gradual and prolonged release of greenhouse gases (Schuur et al. 2015), but also indicating that a significant amount of carbon would be released in low emission pathways before 2100 .

The extra warming caused by the permafrost carbon feedback (PCF) has been investigated (see MacDougall et al. 2012, Schneider von Deimling et al. 2012; Burke et al. 2012 and Schaefer et al. 2014). However, this feedback is not currently incorporated in economic assessment models (Stern 2016). The additional economic damage caused by permafrost carbon release was analysed (Hope and Schaefer 2015). In comparison to their study which focused on economic damages, we are interested in studying the implications of permafrost thawing within a climate change control setting. More specifically, we estimate the additional efforts required to maintain a radiative forcing of $2.6 \mathrm{~W}$ per $\mathrm{m}^{2}\left(\mathrm{Wm}^{-2}\right)$ in 2100 when adding the extra emissions from permafrost thawing.

\section{Materials and methods}

\subsection{Climate change control scenarios}

We set a radiative forcing target of $2.6 \mathrm{Wm}^{-2}$ for the year 2100 (allowing for "overshooting" during the century) following the RCP approach used by IPCC (see IPCC 2013). We consider two scenarios: The first scenario does not consider the permafrost carbon feedback (Scenario $R C P 2.6$ ) while the second one does (Scenario RCP2.6_PCF). Scenario RCP2.6 introduces the constraint that the total radiative forcing should be equal to $2.6 \mathrm{Wm}^{-2}$ in 2100 , which according to IPCC (2013) corresponds to likely ${ }^{1}$ remaining below a $2{ }^{\circ} \mathrm{C}$ temperature increase. To be consistent with RCP scenarios from literature, we consider that the exogenous radiative forcing from non- $\mathrm{CO}_{2}$ factors increases from 0.25 to $0.4 \mathrm{Wm}^{-2}$ and that land-use emissions are reduced progressively to zero by 2100 (IIASA 2015, Van Vuuren et al. 2011). Scenario $R C P 2.6$ PCF corresponds exactly to Scenario RCP2.6 but includes emissions from permafrost. This scenario therefore requires that the emissions of fossil fuel and industrial $\mathrm{CO}_{2}$ need to be reduced more to achieve the same climate target.

\subsection{Emissions from permafrost}

We use the study from Schneider von Deimling et al. 2015 which includes the most recent available projections of $\mathrm{CO}_{2}$ and $\mathrm{CH}_{4}$ fluxes ${ }^{2}$ from thawing permafrost under the RCP2.6 scenario (Fig. 1). In their estimation the emissions from permafrost peak during the second half

\footnotetext{
${ }^{1}$ Note that according to some authors (Rockström et al. 2009) a $2.6 \mathrm{Wm}^{-2}$ forcing could trigger "slow feedback" mechanisms or tipping points (Lenton et al. 2008) which may move the climate system beyond $2{ }^{\circ} \mathrm{C}$.

${ }^{2}$ Methane was converted to $\mathrm{CO}_{2}$-eq. using a Global Warming Potential factor of 34 (for 100-year time horizon), following the recommendation of IPCC (2013).
} 
Fig. 1 Emissions release from permafrost under the RCP 2.6 scenario $\left(\mathbf{G t C O}_{2}-\mathbf{e q} \mathbf{y}^{-\mathbf{1}}\right)$. The blue lines indicate emissions of permafrost carbon feedback: median (solid), 16th percentile (dotted) and 84th percentile (dashed) pathway (Schneider von Deimling et al. 2015). The red solid line at 0 line refers to the scenario without permafrost thawing

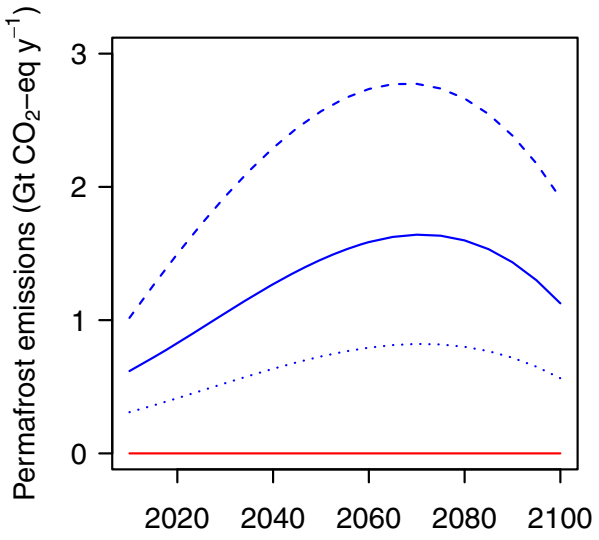

of the century and then decline. The emissions continue beyond 2100 , however as they are monotonously declining it is feasible to set a control target in 2100. The only source of uncertainty we include relates to the $68 \%$ confidence interval on the permafrost emission estimates by these authors. Although many other sources of uncertainty are present, the goal of our study is not to conduct a probabilistic analysis but to estimate how the expected permafrost carbon feedback impacts climate change control all other factors being equal.

\subsection{Integrated assessment model}

We use the Dynamic Integrated Climate-Economy model (DICE version 2013R, Nordhaus and Sztorc 2013), a well-known integrated assessment model (IAM) of climate-change economics (Nordhaus 1992, 2014; Butler et al. 2014; Moore and Diaz 2015). In this approach, society invests in capital goods, thereby reducing consumption today, in order to increase consumption in the future. Investing in emissions reduction reduces consumption today but prevents future damage from climate change. In our study an optimal path for fossil fuel and industrial $\mathrm{CO}_{2}$ emission reduction is sought that maximizes the net present value of cumulative economic welfare from 2010 to 2100 subject to a constraint ${ }^{3}$ on radiative forcing $\left(2.6 \mathrm{Wm}^{-2}\right.$ in 2100$)$. In this approach economic welfare corresponds to net welfare, i.e. the damages ${ }^{4}$ from climate change and the mitigation costs have already been deducted. More detailed technical information on DICE can be found in Nordhaus and Sztorc (2013).

\section{Results}

Figure 2a depicts the resulting $\mathrm{CO}_{2}$ emission pathways to reach the $2.6 \mathrm{Wm}^{-2}$ climate change control target ${ }^{5}$. The results indicate that in the presence of a permafrost carbon feedback the

\footnotetext{
${ }^{3}$ In this study we set an exogenous constraint of $2.6 \mathrm{Wm}^{-2}$; Notice that if the DICE model were be run without constraints the optimal value obtained would be beyond this level of radiative forcing (see Nordhaus and Sztorc 2013)

${ }^{4}$ The damages from climate change involve large uncertainties, especially for high emissions and large temperature changes (Pindyck 2013). However, here the choice of the damage function is less relevant as we analyse a low carbon emission scenario.
} 
a

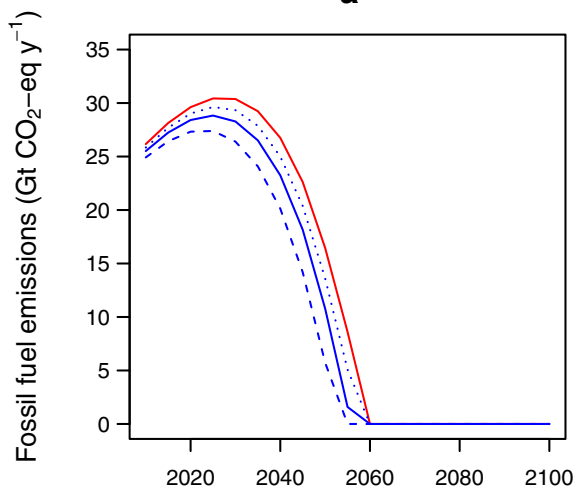

b

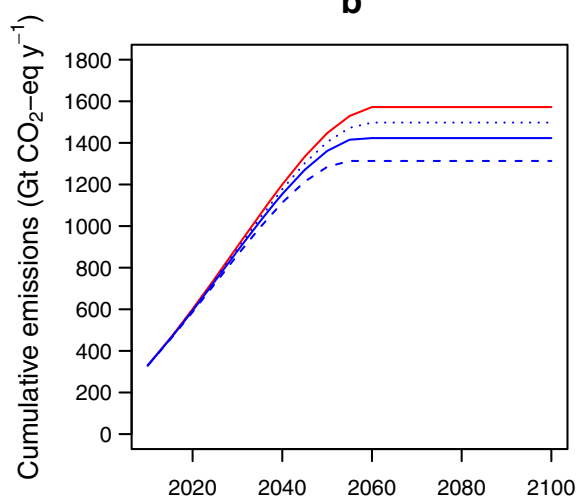

C

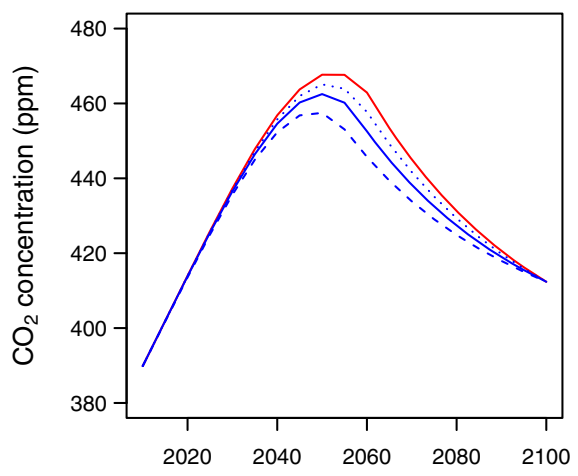

d

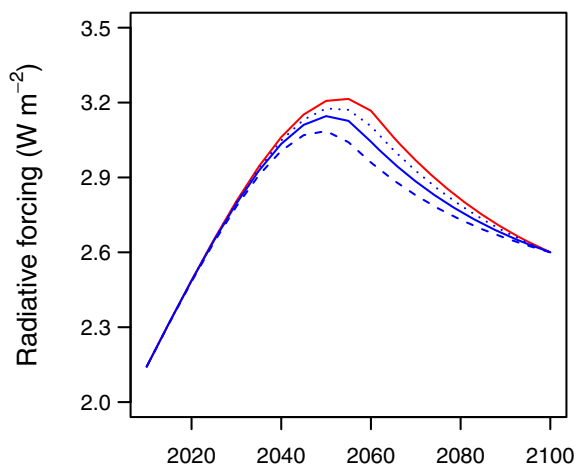

Fig. 2 Climate change control under permafrost carbon feedback. Pathway for 2010-2100 without (red) and with permafrost thawing (blue) a) Fossil fuel and industrial $\mathrm{CO}_{2}$ emissions, b) Cumulative fossil fuel and industrial $\mathrm{CO}_{2}$ emissions, c) $\mathrm{CO}_{2}$ concentration in the atmosphere and d) Radiative forcing. The dashed and dotted line indicate the $68 \%$ confidence interval associated with the permafrost emission estimates

fossil fuel and industrial $\mathrm{CO}_{2}$ emissions need to peak between 5 to 10 years earlier. The carbon budget needs to be reduced from $1570 \mathrm{GtCO}_{2}$ to 1420 [1310-1500] $\mathrm{GtCO}_{2}$, equivalent to a 10 [5.7-16.5] \% reduction (Fig. 2b). The $\mathrm{CO}_{2}$ concentration in the atmosphere would be slightly lower during the entire century (Fig. 2c).

The required reductions of fossil fuel and industrial $\mathrm{CO}_{2}$ emissions of 149.1 [74.6-259.0] $\mathrm{GtCO}_{2}$ are higher than the cumulative emissions generated along the century from permafrost (122.0 [61.0-211.0] $\mathrm{GtCO}_{2}$-eq). This is because the overshooting potential is reduced (see Fig. 2d) due to the presence of continued emissions from permafrost in the second half of the century.

In summary, the presence of a permafrost carbon feedback requires that the reduction of fossil fuel and industrial $\mathrm{CO}_{2}$ emissions needs to be greater and occur earlier. This implies that the price (tax) of carbon must be higher, both now and in the future (Fig. 3a). In the absence of the permafrost carbon feedback the global price of $\mathrm{CO}_{2}$ (assuming full participation) would need to rise from $36 \mathrm{US} \$ / \mathrm{tCO}_{2}$ in 2015 to $180 \mathrm{US} \$ / \mathrm{tCO}_{2}$ in 2050 . In the presence of a permafrost carbon feedback the respective increase would need to be from 41[38-46] US\$/ $\mathrm{tCO}_{2}$ in 2015 to 210 [200-240] $\mathrm{US} \$ / \mathrm{tCO}_{2}$ in 2050 (Fig. 3a). 
a

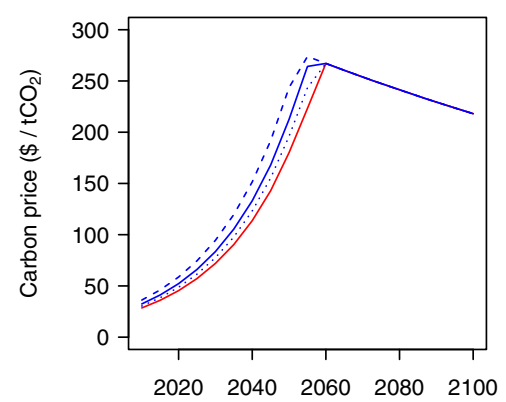

b

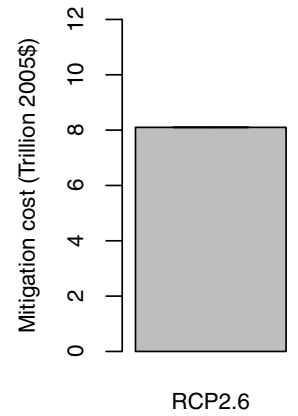

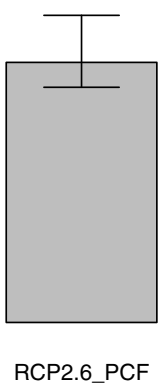

Fig. 3 Economic implications of permafrost carbon feedback. a Carbon price without (red) and with permafrost carbon feedback (blue). The dashed and dotted line indicate the $68 \%$ confidence interval associated with the permafrost emission estimates. b mitigation cost without (RCP2.6) and with permafrost carbon feedback (RCP2.6 PCF)

The higher carbon price implies higher costs to society. The presence of a permafrost carbon feedback would increase the mitigation cost from US\$8.1 to US\$9.0 [8.5-9.8] trillion, equivalent to a 6-21\% increase (Fig. 3b). Devoting more resources to mitigation implies a reduction of consumption and investment, implying a loss in welfare. Our results show that the net present value of total welfare from 2010 to 2100 is reduced due to permafrost carbon feedback by US\$ $4.2[2-7.8]$ trillion.

\section{Sensitivity analysis for the mitigation cost}

The mitigation costs obtained in our study are in the low range of the literature (see Clarke et al. 2014). There are two important factors explaining this result: the first being the discount rate $^{5}$ and the second the cost of the backstop technology. ${ }^{6}$ To address this, we have studied (Table 1) the sensitivity of the mitigation cost towards changes in i) the pure rate of social time preference $(\rho)$ and ii) the cost of backstop technology (pback).

The results for the default values of the DICE model (pure rate of social time preference of $1.5 \%$ and a backstop technology at $\$ 344$ per ton of $\mathrm{CO}_{2}$ ) have been described in section 3. As expected, the mitigation costs increase for lower discount rates and for higher prices of backstop technology. In the case of a pure rate of social time preference of $0.1 \%$ (similar to the one used in Stern 2008) and a backstop technology price of $1000 \mathrm{US} / t \mathrm{CO}_{2}$, the present value of mitigation cost would be US\$78.2 trillion for the RCP2.6 scenario and would rise to US\$84.0 [81.0-88.6] trillion when including the permafrost carbon feedback. Conversely, with a pure rate of social time preference of $3 \%$ and with a backstop technology at $100 \mathrm{US} \$ / \mathrm{tCO}_{2}$,

\footnotetext{
${ }_{5}$ The discount rate is made up of two components: The pure rate of social time preference $\rho$ and the rate of inequality aversion $\alpha$. Following Nordhaus 2014, the decrease in social time preference to $0.1 \%$ is compensated for by increasing the risk aversion parameter from $\alpha=1.45$ to $\alpha=2.1$. Although there is an ongoing discussion if the social discount rates should be consistent with market discount rates (see Stern 2008 and Nordhaus 2014), this is an issue beyond the scope of this paper.

${ }^{6}$ In DICE, this backstop technology is available at $344 \mathrm{US} \$ / \mathrm{tCO}_{2}$ (2005 US\$, at $100 \%$ removal) in 2010 declining at $0.5 \%$ per year. This effect can be observed in Fig. 3a where the carbon price cannot increase beyond that limit.
} 
Table 1 Sensitivity analysis for the mitigation costs (Trillion USD 2005). The table shows the results for alternative values for pure rate of social time preference $(\rho)$ and cost of backstop technology (pback). The results are shown for RCP2.6 scenario (no permafrost carbon feedback) and for RCP2.6 PCF scenario (with permafrost carbon feedback). The values in brackets refer to the $68 \%$ confidence interval associated with the permafrost emission estimates. The column ( $\rho=0.1 \%$ Recalibrated), following Nordhaus 2014, refers to a situation where the decrease in pure rate of social time preference is compensated for by increasing the risk aversion parameter (from $\alpha=1.45$ to $\alpha=2.1$ ) in order to maintain the market discount rate

\begin{tabular}{|c|c|c|c|c|c|}
\hline \multirow{2}{*}{$\begin{array}{l}\text { Cost of backstop } \\
\text { technology }(\text { pback, } \\
\left.2005 \text { US } \$ / \mathrm{tCO}_{2}\right)\end{array}$} & \multirow[t]{2}{*}{ Scenarios } & \multicolumn{4}{|c|}{ Pure rate of social time preference $(\rho, \%)$} \\
\hline & & 0.1 & 1.5 & 3 & $\begin{array}{l}0.1 \\
\text { (Recalibrated) }\end{array}$ \\
\hline \multirow[t]{3}{*}{100} & RCP2.6 & 8.3 & 2.4 & 0.8 & 2.5 \\
\hline & RCP2.6_PCF & $8.8[8.5-9.2]$ & $2.7[2.5-2.9]$ & $0.9[0.9-1.0]$ & $2.7[2.6-3.0]$ \\
\hline & $\%$ change & $3-12 \%$ & $5-20 \%$ & $8-30 \%$ & $5-21 \%$ \\
\hline \multirow[t]{3}{*}{344} & RCP2.6 & 27.6 & 8.1 & 2.6 & 8.3 \\
\hline & RCP2.6_PCF & $29.6[28.6-31.5]$ & $9.0[8.5-9.8]$ & $3.1[2.9-3.5]$ & $9.2[8.7-10.0]$ \\
\hline & $\%$ change & $4-13 \%$ & $6-21 \%$ & $8-32 \%$ & $5-21 \%$ \\
\hline \multirow[t]{3}{*}{1000} & RCP2.6 & 78.2 & 22.9 & 7.5 & 23.5 \\
\hline & RCP2.6_PCF & $84.0[81.0-88.6]$ & $25.6[24.2-27.8]$ & $8.7[8.1-9.9]$ & $26.8[24.8-28.4]$ \\
\hline & $\%$ change & $4-13 \%$ & $6-21 \%$ & $8-32 \%$ & $5-19 \%$ \\
\hline
\end{tabular}

the present value of mitigation cost would be US\$0.8 trillion in the RCP2.6 scenario and US\$0.9 [0.9-1.0] trillion when including the permafrost carbon feedback.

Following Nordhaus 2014, we include an additional scenario ( $\rho=0.1 \%$ Recalibrated $)$, which refers to a situation where the decrease in pure rate of social time preference is compensated for by increasing the risk aversion parameter in order to maintain the market discount rate. As expected, the cost of mitigation is significantly lowered through recalibration and the results are very close to those obtained with $\rho=1.5 \%$.

The sensitivity analysis shows that the discount rate and the price of backstop technology significantly impact the mitigation costs. However, more importantly for our study, the relative additional mitigation costs are far less affected (Table 1).

\section{Conclusions}

Much of the current evidence on permafrost thawing has appeared subsequently to the Fifth Assessment Report (AR5) of the Intergovernmental Panel on Climate Change (IPCC) and has therefore not yet been included in the integrated assessment models (Schaefer et al. 2014). Our study shows significant consequences for climate change control. Thus the task of keeping warming below $2{ }^{\circ} \mathrm{C}$ becomes more challenging when considering the additional emissions from thawing permafrost. It is important to realise that permafrost thawing may not be the only feedback due to rapid Arctic change (Duarte et al. 2012) currently excluded from integrated assessment models. Other examples are the possibility of an abrupt melting of hydrates beneath the East Siberian Sea (Shakhova et al. 2010 and Whiteman et al. 2013) or a possible underestimation of the albedo feedback effect due to sea ice melting (Pistone et al. 2014). 
Acknowledgments The authors thank Iñigo Capellán-Perez, Juan-Carlos Ciscar, Thomas Schneider von Deimling, Jon Sampedro, Paul Sztorc, Dirk-Jan. van de Ven and two anonymous referees for valuable comments that helped us improve the manuscript. This study received funding from the European Union's Horizon 2020 research and innovation programme under grant agreement No 642260 (TRANSrisk project). Mikel GonzalezEguino also acknowledges financial support from the Ministry of Economy and Competitiveness of Spain (ECO2015-68023) and the Basque Government (IT-799-13). Marc B. Neumann acknowledges financial support from the Ramón y Cajal Research Fellowship of the Ministry of Economy and Competitiveness of Spain (no. RYC-2013-13628). The authors declare that there are no conflicts of interest.

Open Access This article is distributed under the terms of the Creative Commons Attribution 4.0 International License (http://creativecommons.org/licenses/by/4.0/), which permits unrestricted use, distribution, and reproduction in any medium, provided you give appropriate credit to the original author(s) and the source, provide a link to the Creative Commons license, and indicate if changes were made.

\section{References}

Brown J, Romanovsky VE (2008) Report from the international permafrost association: state of permafrost in the first decade of the 21st century. Permafr Periglac Process 19(2):255-260

Burke EJ, Jones CD, Koven CD (2012) Estimating the permafrost-carbon climate response in the CMIP5 climate models using a simplified approach. J Clim 26(14):4897-4909

Butler MP, Reed PM, Fisher-Vanden K, Keller K, Wagener T (2014) Inaction and climate stabilization uncertainties lead to severe economic risks. Clim Chang 127(3-4):463-474

Clarke L, Jiang K, Akimoto K, Babiker M, Blanford G, Fisher-Vanden K, Hourcade JC, Krey V, Kriegler E, Löschel A, McCollum D, Paltsev S, Rose S, Shukla PR, Tavoni M, van der Zwaan BCC, van DP Vuuren (2014) Assessing transformation pathways. In: Climate change 2014: Mitigation of climate change. Contribution of working group III to the fifth assessment report of the intergovernmental panel on climate change. Cambridge University Press, Cambridge, United Kingdom and New York, NY, USA

Duarte CM, Lenton TM, Wadhams P, Wassmann P (2012) Abrupt climate change in the Arctic. Nat Clim Chang 2(2):60-62

Hope C, Schaefer K (2016) Economic impacts of carbon dioxide and methane released from thawing permafrost. Nat Clim Chang 6:56-59

IIASA (2015) RCP Database, Version 2.0. Institute for Applied Systems Analysis (IIASA), Austria. Available at: http://www.iiasa.ac.at/web-apps/tnt/RcpDb

IPCC (2013) In: TF Stocker, Qin D, GK Plattner, Tignor M, SK Allen, Boschung J, Nauels A, Xia Y, Bex V, PM Midgley (eds) Climate change 2013: the physical science basis. Contribution of working group I to the fifth assessment report of the intergovernmental panel on climate change. Cambridge University Press, Cambridge

Lenton TM, Held H, Kriegler E, Hall JW, Lucht W, Rahmstorf S, Schellnhuber HJ (2008) Tipping elements in the Earth's climate system. Proc Natl Acad Sci USA 105(6):1786-1793

MacDougall AH, Avis CA, Weaver AJ (2012) Significant contribution to climate warming from the permafrost carbon feedback. Nat Geosci 5(10):719-721

Moore FC, Diaz DB (2015) Temperature impacts on economic growth warrant stringent mitigation policy. Nat Clim Chang 5(2):127-131

Nordhaus WD (1992) An optimal transition path for controlling greenhouse gases. Science 258(5086):13151319

Nordhaus WD (2014) Estimates of the social cost of carbon: concepts and results from the DICE-2013R model and alternative approaches. J Assoc Environ Resour Econ 1(1/2):273-312

Nordhaus WD, Sztorc P (2013) DICE 2013R: introduction and user's manual http://www.econ.yale.edu/ $\sim$ nordhaus/homepage

Pindyck RS (2013) Climate change policy: what do the models tell us? J Econ Lit 51(3):860-872

Pistone K, Eisenman I, Ramanathan V (2014) Observational determination of albedo decrease caused by vanishing Arctic Sea ice. Proc Natl Acad Sci USA 111(9):3322-3326

Rockström J, Steffen W, Noone K, Persson A, Chapin FS, Lambin EF, Lenton TM, Scheffer M, Folke C, Schellnhuber HJ, Nykvist B, De Wit CA, Hughes T, van der Leeuw S, Rodhe H, Sörlin S, Snyder PK, Costanza R, Svedin U, Falkenmark M, Karlberg L, Corell RW, Fabry VJ, Hansen J, Walker B, Liverman D, Crutzen P, Foley JA (2009) A safe operating space for humanity. Nature 461(7263):472-475

Schaefer K, Lantuit RVE, Schuur EAG, Witt R (2014) The impact of the permafrost carbon feedback on global climate. Environ Res Lett 9(8) 
Schuur EAG, Bockheim J, Canadell JG, Euskirchen FCB, Goryachkin SV, Hagemann S, Hagemann S, Kuhry P, Lafleur PM, Lee H, Mazhitova G, Nelson FE, Rinke A, Romanovsky VE, Shiklomanov N, Tarnocai C, Venevsky S, Vogel JG, Zimov SA (2008) Vulnerability of permafrost carbon to climate change: implications for the global carbon cycle. Bioscience 58(8):701-714

Schuur EAG, McGuire AD, Schädel C, Grosse G, Harden JW, Hayes DJ, Hugelius G, Koven CD, Kuhry P, Lawrence DM, Natali SM, Olefeldt D, Romanovsky VE, Schaefer K, Turetsky MR, Treat CC, Vonk JE (2015) Climate change and the permafrost carbon feedback. Nature 520(7546):171-179

Shakhova NE, Alekseev VA, Semiletov IP (2010) Predicted methane emission on the East Siberian Shelf. Dokl Earth Sci 430(2):190-193

Stern N (2008) The economics of climate change. Am Econ Rev 98(2):1-37

Stern N (2016) Economics: current climate models are grossly misleading. Nature 30(7591):407

von Deimling ST, Meinshausen M, Levermann A, Huber V, Frieler K, Lawrence DM, Brovkin V (2012)

Estimating the near-surface permafrost-carbon feedback on global warming. Biogeosciences 9(2):649-665

von Deimling ST, Grosse G, Strauss J, Schirrmeister L, Morgenstern A, Schaphoff S, Meinshausen M, Boike J (2015) Observation-based modelling of permafrost carbon fluxes with accounting for deep carbon deposits and thermokarst activity. Biogeosciences 12(11):3469-3488

van Vuuren DP, Stehfest E, den Elzen MGJ, Kram T, van Vliet J, Deetman S, Isaac M, Goldewijk KK, Hof A, Beltran MA, Oostenrijk R, van Ruijven B (2011) RCP2.6: exploring the possibility to keep global mean temperature increase below $2{ }^{\circ} \mathrm{C}$. Clim Chang 109(1-2):95-116

Whiteman G, Chris H, Wadhams P (2013) Climate science: vast costs of Arctic change. Nature 499(7459):401403

Zhang T, Barry RG, Knowles K, Heginbottom JA, Brown J (2008) Statistics and characteristics of permafrost and ground-ice distribution in the northern hemisphere. Polar Geogr 31(1-2):47-68

Zimov SA, Schuur EAG, Chapin FS (2006) Permafrost and the global carbon budget. Science 312(5780):16121613 